\title{
Lethal Efficacy of Banana Leaves Extract (Musa paradisiaca L.) Against Aedes aegypti Larvae
}

\section{Daya Bunuh Ekstrak Daun Pisang (Musa paradisiaca L.) Terhadap Larva Aedes aegypti}

Wihdatul Karima, Syahrul Ardiansyah*

Teknologi Laboratorium Medis, Fakultas IImu Kesehatan, Universitas Muhammadiyah Sidoarjo, Jl. Raya Rame Pilang No. 4 Wonoayu, Sidoarjo, 61261, Jawa Timur, Indonesia. Tel.: (031) 8962733

Indonesia has a potential to be exposed to the threat of dengue hemorrhagic fever with the point vector, the Aedes aegypti mosquito, so development need to be stopped. The use of synthetic larvicides in eradicating mosquito larvae can cause environmental pollution. To reduce it, an alternative is needed using plant larvacides with banana leaf. Banana leaves are obtained from Candi Sidoarjo. Ethanol extract of banana leaf contains tannin compounds, alkaloids, terpenoids, saponins, and flavonoids which can be used as larvicides. This research was conducted to determine the toxic effects of banana leaf extract (Musa paradisiaca L.) on the larvae of Aedes aegypti mosquito mortality. This research was conducted using the post test only the control group design with 6 treatment groups including control (aquades) and banana leaf extract concentrations of 1000 ppm, 2000 ppm, 3000 ppm, 4000 ppm, $5000 \mathrm{ppm}$. This study used third instar larvae, each test group countaining 20 larvae

OPEN ACCESS ISSN 2580-7730 (online)

Edited by: Andika Aliviameita

Reviewed by: Yos Adi Prakoso

*Correspondence:

Syahrul Ardiansyah syahrulardiansyah@umsida.ac.id

Received: 18 Februari 2021 Accepted: 26 April 2021 Published: 31 Juli 2021

Citation:

Karima W and Ardiansyah S (2021) Lethal Efficacy of Banana Leaves Extract (Musa paradisiaca L.)

Against Aedes aegypti Larvae Medicra (Journal of Medical Laboratory Science/Technology).

doi: 10.21070/medicra.v4i1.881 with 4 repetitions. That obtained were analyzed using data and probit tests. The results of this study that banana leaf extract has a toxic effect on Aedes aegypti mosquito larvae with LC50 at a concentration of $4638 \mathrm{ppm}$.

Keywords: Aedes aegypti, banana leaf extract, dengue fever, larvaside, lethal efficacy

Indonesia berpotensi terkena ancaman penyakit demam berdarah dengue dengan vektor utama yaitu nyamuk Aedes aegypti sehingga perlu dihentikan perkembangannya. Penggunaan larvasida sintetis dalam membasmi larva nyamuk dapat menimbulkan pencemaran lingkungan. Untuk menguranginya diperlukan adanya alternatif dengan menggunakan larvasida nabati berasal dari daun pisang. Daun pisang diperoleh dari Candi Sidoarjo. Ekstrak etanol daun pisang mengandung senyawa tanin, alkaloid, terpenoid, saponin, dan flavonoid yang dapat digunakan sebagai larvasida. Penelitian ini dilakukan untuk mengetahui efek toksik ekstrak daun pisang (Musa paradisiaca L.) terhadap mortalitas larva nyamuk Aedes aegypti. Penelitian ini dilakukan dengan metode post test only control group design dengan 6 kelompok perlakuan diantaranya kontrol (aquades) dan ekstrak daun pisang konsentrasi 1000 ppm, 2000 ppm, 3000 ppm, 4000 ppm, 5000 ppm. Penelitian menggunakan larva, setiap kelompok uji menghitung 20 larva dengan 4 ulangan. 
Data yang diperoleh dilakukan analisa data dan uji probit. Hasil dari penelitian ini dapat dikatakan bahwa ekstrak daun pisang memiliki efek toksik terhadap larva nyamuk Aedes aegypti dengan LC50 pada konsentrasi 4638 ppm.

Kata Kunci: Aedes aegypti, daya bunuh, demam berdarah, larvasida, ekstrak daun pisang 


\section{PENDAHULUAN}

DBD telah menjadi masalah masyarakat Indonesia selama 47 tahun terakhir. Peningkatan jumlah terjadinya DBD ini dimulai dari tahun 1968 yaitu 58 kasus berubah menjadi 126.675 kasus pada tahun 2015 Kemenkes RI (2016). Metode yang paling efektif untuk membunuh vektor yang dapat menyebabkan penyakit DBD yaitu dapat dilakukan dengan mencegah larva nyamuk yang berkembangbiak dengan menggunakan larvasida. Penggunaan larvasida dapat mematikan larva nyamuk sehingga nyamuk tidak dapat tumbuh menjadi nyamuk dewasa dan pada akhirnya tidak dapat menyebarkan wabah penyakit DBD Deded et al. (2013).

Banyak masyarakat dalam mengendalikan vektor tersebut dengan cara penggunaan larvasida kimia WHO (2011). Adapun kekurangan dalam penggunaan larvasida kimia, yaitu dapat menimbulkan resiko kontaminasi residu pestisida dalam air, terutama air minum dalam penggunaan yang berulang Riyadi et al. (2018). Sehingga perlu adanya bahan alternatif sebagai pengganti bahan kimia yang digunakan sebagai larvasida. Dampak merugikan akibat menggunakan insektisida kimiawi yaitu dapat menyebabkan resistensi terhadap serangga, mengganggu kesehatan dan pencernaan lingkungan Raharjo (2006).

Salah satu sarana pengendalian hama yang layak dikembangkan yaitu insektisida nabati, karena senyawa insektisida dari tumbuhan tidak meninggalkan residu di udara, mudah terurai di lingkungan, tanah, dan air. Serta mempunyai tingkat keamanan yang lebih tinggi bila dibandingkan dengan racun-racun anorganik Listyorini (2012). Salah satu tanaman yang dapat digunakan sebagai insektisida alami yaitu tanaman pisang. dalam uji fitokimia bahwa daun pisang memiliki kandungan senyawa kimia tanin, alkaloid, terpenoid, saponin, flavonoid, glikosida jantung, gula deoksi, dan karbohidrat Asuquo and Udobi (2016). Senyawa kimia yang terdapat pada tanaman tersebut bersifat larvasida Haditomo (2010).

Beberapa penelitian sebelumnya melaporkan bahwa ekstrak kulit pisang dapat dijadikan anti-larvasida terhadap nyamuk $A$. aegypti dan memiliki hubungan korelasi yang kuat dimana setiap penambahan konsentrasi larva berpengaruh terhadap jumlah kematian larva Jamal et al. (2016). Penelitian lain menyebutkan ekstrak metanol bonggol pisang ambon memiliki efek mortalitas tertinggi pada larva sebesar 71,67\% pada konsentrasi 1000 ppm Komala et al. (2018). Kemudian adapun uji pendahuluan yang dilakukan oleh Rathy et al. (2015) bahwa gagang bunga pisang (Musa paradisiaca L.) memiliki kemampuan mortalitas $100 \%$ terhadap larva $A$. aegypti pada konsentrasi $0,5 \mathrm{ml}$ dalam waktu $24 \mathrm{jam}$. Tetapi belum ada penelitian tentang efektivitas daun pisang sebagai larvasida, sehingga perlu dilakukan penelitian untuk mengetahui efektivitas ekstrak daun pisang sebagai larvasida terhadap mortalitas larva A. aegypti.

\section{METODE}

Penelitian ini merupakan penelitian eksperimen (experimental) dengan rancangan post test only control group design yaitu desain penelitian yang tidak menggunakan pretes terhadap sampel sebelum dilakukan perlakuan. Desain penelitian ini mengukur pengaruh perlakuan pada kelompok eksperimen dengan cara membandingkan kelompok konsentrasi ekstrak daun pisang (Musa paradisiaca L.) dengan kelompok kontrol.Penelitian ini menggunakan 6 kelompok perlakuan yang terdiri dari 5 kelompok perlakuan dan 1 kelompok kontrol dan dilakukan pengulangan sebanyak 4 kali pada setiap perlakuan.

Larva nyamuk A.aegypti yang digunakan adalah pada masa instar III dengan ukuran 4-5 mm, larva tersebut diletakkan pada wadah aquarium atau gelas beaker $1000 \mathrm{ml}$.

Pembuatan ekstrak daun pisang dilakukan dengan cara membersihkan daun pisang dengan air kemudian menjemur daun pada tempat yang terbuka tetapi tidak boleh terkena matahari secara langsung selama \pm 7 hari. Setelah kering dihaluskan daun tersebut hingga menjadi serbuk halus. Kemudian ditimbang serbuk untuk diketahui berat dari serbuk yang diperoleh kemudian direndam dengan pelarut etanol 96\% selama 3 x 24 jam. Proses selanjutnya yakni dilakukan evaporasi guna dihilangkan etanol yang terkandung dalam larutan sehingga diperoleh hasil berupa repellent ekstrak pekat daun pisang dalam bentuk setengah padat (kental).

Pembuatan stok ekstrak daun pisang dilakukan untuk menghindari penimbangan berulang-ulang. Pembuatan larutan stok ekstrak daun pisang 5000 ppm sebanyak $1500 \mathrm{ml}$ dilakukan dengan menimbang ekstrak sebanyak 7,5 gram ekstrak kemudian melarutkannya dengan aquades hingga $1500 \mathrm{ml}$. Untuk membuat berbagai macam konsentrasi yang diperlukan dalam penelitian ini dapat dilakukan dengan menggunakan rumus:

$$
\mathrm{V} 1 . \mathrm{M} 1=\mathrm{V} 2 . \mathrm{M} 2
$$

Larutan yang berisi ekstrak etanol daun pisang dipersiapkan, lalu dipindahkan kedalam beaker glass yang telah dipersiapkan dan dibagi menjadi 6 kelompok perlakuan secara merata mulai dari kontrol negatif (aquades) dan sederet konsentrasi ekstrak daun pisang 1000 ppm, 2000 ppm, 3000 ppm, 4000 ppm, 5000 ppm.

Data penelitian ini merupakan data primer yang diambil berdasarkan teknik observasi langsung (pengamatan), dengan menghitung jumlah kematian larva selama 96 jam dalam 24 jam pertama dilakukan pengamatan secara intens setiap 1 jam sekali pada tiap kelompok perlakuan. Larva dapat dikatakan mati jika tenggelam kedasar beaker glass, tidak bergerak, dan tidak adanya respon terhadap rangsangan. Presentase mortalitas larva dapat dihitung dengan menggunakan rumus:

$$
M=\frac{M t}{M o} \times 100 \%
$$


Data pada penelitian ini dianalisis dengan menggunakan software statistic SPSS 16. Data yang telah diperoleh dilakukan uji analisis regresi probit untuk menentukan Lethal Concentration (LC) yaitu konsentrasi yang dibutuhkan untuk membunuh 50\% larva. Kemudian dilanjutkan dengan uji Kruskall Wallis dan Mann Whitney yang bertujuan untuk membandingkan signifikasi antar kelompok.

\section{HASIL DAN PEMBAHASAN}

Hasil penghitungan jumlah kematian larva instar III setelah 96 jam perlakuan disajikan pada Tabel 1, sedangkan grafik jumlah kematian larva disajikan pada Gambar 1.

TABEL 1. Data Kematian Larva Aedes aegypti

\begin{tabular}{|c|c|c|c|c|c|}
\hline No & $\begin{array}{l}\text { Kelompok } \\
\text { perlakuan }\end{array}$ & $\begin{array}{l}\text { Jumlah } \\
\text { awal } \\
\text { larva } \\
\text { A.aegypti }\end{array}$ & $\begin{array}{l}\text { Perlakuan dan } \\
\text { total larva } \\
\text { A.aegypti yang mati }\end{array}$ & $\begin{array}{l}\text { Rata- } \\
\text { rata }\end{array}$ & $\begin{array}{l}\text { Per } \\
\text { se } \\
\text { nta } \\
\text { se } \\
(\%)\end{array}$ \\
\hline
\end{tabular}

\begin{tabular}{|c|c|c|c|c|c|c|c|c|}
\hline & & & 1 & 2 & 3 & 4 & & \\
\hline 1 & $\begin{array}{l}\text { Kontrol } \\
\text { negatif } \\
\text { (Aquades) }\end{array}$ & 20 & 0 & 0 & 0 & 0 & 0 & 0 \\
\hline 2 & 1000 ppm & 20 & 0 & 1 & 1 & 1 & 0,75 & 4 \\
\hline 3 & $2000 \mathrm{ppm}$ & 20 & 3 & 2 & 1 & 1 & 1,75 & 9 \\
\hline 4 & $3000 \mathrm{ppm}$ & 20 & 5 & 4 & 3 & 4 & 4 & 20 \\
\hline 5 & 4000 ppm & 20 & 7 & 8 & 6 & 9 & 7,5 & 38 \\
\hline 6 & $5000 \mathrm{ppm}$ & 20 & 14 & 12 & 10 & 10 & 11,5 & 58 \\
\hline
\end{tabular}

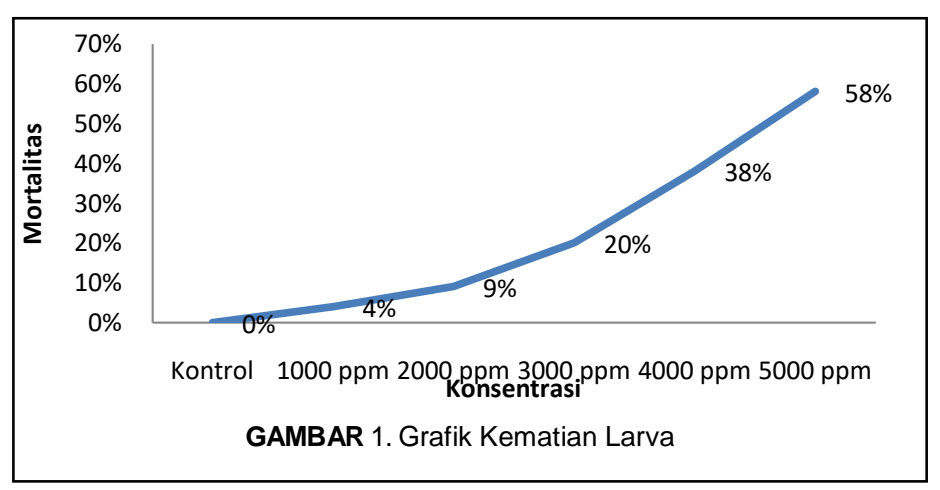

TABEL 2. Hasil Analisa Probit

\begin{tabular}{cccc}
\hline & $\begin{array}{c}\text { Konsentrasi } \\
(\mathrm{ppm})\end{array}$ & $\begin{array}{c}\text { Konsentrasi } \\
\text { Maximum } \\
(\mathrm{ppm})\end{array}$ & $\begin{array}{c}\text { Konsentrasi } \\
\text { Minimum } \\
(\mathrm{ppm})\end{array}$ \\
$\mathrm{LC50}$ & 4638 & 9780 & 3645 \\
\hline
\end{tabular}

Dapat diketahui dari Tabel 1 bahwa pada kontrol negatif tidak ditemukan adanya kematian larva selama 96 jam hal tersebut membuktikan bahwa kematian larva tidak dipengaruhi oleh faktor lingkungan, tetapi dipengaruhi oleh senyawa yang ada pada ekstrak daun pisang. Pemberian ekstrak etanol daun pisang presentase kematian dari terendah yaitu 1000 ppm dengan rata-rata jumlah kematian 1 larva (4\%), sedangkan rata-rata kematian tertinggi terdapat pada konsentrasi 5000 ppm dengan rata-rata jumlah kematian sebanyak 11 larva (58\%).

Berdasarkan Gambar 1 menunjukkan hasil ekstrak dapat dilihat dimana kematian larva berbanding lurus dengan konsentrasi yaitu semakin tinggi konsentrasi ekstrak maka presentase kematian juga akan meningkat. Hasil tersebut disebabkan karena semakin tinggi konsentrasi yang digunakan maka semakin tinggi pula kandungan senyawa bio-aktif yang terkandung. Tingkat konsentrasi yang dapat menyebabkan kematian ditentukan dengan nilai konsentrasi letal $50\left(\mathrm{LC}_{50}\right)$. Hal ini diperlukan untuk mengetahui jumlah penggunaan

Tabel 2 merupakan hasil dari uji probit $\mathrm{LC}_{50}$. Hasil analisa probit dari penelitian ini diperoleh hasil $4638 \mathrm{ppm}$ yang artinya larva akan mati sebesar 50\% jika pada konsentrasi 4638 ppm. Hasil tersebut lebih rendah dari konsentrasi uji yang digunakan yaitu $5000 \mathrm{ppm}$ yang membunuh larva nyamuk sebanyak $58 \%$ dari seluruh populasi sampel yang digunakan dalam penelitian. Sehingga dapat dikatan bahwa penelitian ini berhasil mematikan larva sebanyak 50\% dengan konsentrasi 5000 ppm.

TABEL 3. Hasil Uji Mann Whitney

\begin{tabular}{|c|c|c|c|c|c|c|}
\hline & Kontrol & $\begin{array}{l}1000 \\
\mathrm{ppm}\end{array}$ & $\begin{array}{r}2000 \\
\text { ppm }\end{array}$ & $\begin{array}{c}3000 \\
\mathrm{ppm}\end{array}$ & $\begin{array}{l}4000 \\
\mathrm{ppm}\end{array}$ & $\begin{array}{l}5000 \\
\mathrm{ppm}\end{array}$ \\
\hline & Sig & Sig & Sig & Sig & Sig & Sig \\
\hline Kontrol & & 0,040 & 0,013 & 0,013 & 0,014 & 0,013 \\
\hline $\begin{array}{l}1000 \\
\mathrm{ppm}\end{array}$ & & & 0,098 & 0,017 & 0,018 & 0,017 \\
\hline 2000 ppm & & & & 0,027 & 0,020 & 0,019 \\
\hline $3000 \mathrm{ppm}$ & & & & & 0,020 & 0,019 \\
\hline $4000 \mathrm{ppm}$ & & & & & & 0,020 \\
\hline 5000 ppm & & & & & & \\
\hline
\end{tabular}

Berdasarkan Tabel 1 dan Gambar 1 diketahui bahwa kelompok kontrol tidak terjadi kematian pada larva Aedes aegypti setelah 96 jam perlakuan pada berbagai konsentrasi adalah konsentrasi 0\% (kontrol) rata-rata kematian sebesar 0 larva $(0 \%)$, konsentrasi $1000 \mathrm{ppm}$ rata-rata kematian sebanyak 0,75 (1) larva (4\%), konsentrasi 2000 ppm rata-rata kematian sebanyak 1,75 (2) larva (9\%), konsentrasi 3000 ppm rata-rata kematian sebanyak 4 larva (20\%), konsentrasi 4000 ppm rata-rata kematian sebanyak 7,5 (7) larva (38\%) dan konsentrasi 5000 ppm rata-rata kematian sebanyak 11,5 (11) larva (58\%).

Ekstrak daun pisang (Musa paradisiaca L.) dapat membunuh larva karena ekstrak etanol daun pisang mengandung senyawa tanin, alkaloid, terpenoid, saponin dan flavonoid yang dapat digunakan sebagai larvasida Haditomo (2010). Senyawa-senyawa tersebut masuk ke dalam larva dan menimbulkan kematian pada larva.Senyawa flavanoid masuk ke dalam tubuh larva akan melumpuhkan sistem saraf pernafasan sehingga larva akan mengalami kejang, kemudian mati kesulitan bernafas dikarenakan adanya gangguan pada 
sistem pernafasan Nadila et al. (2017). Saponin yang masuk ke dalam tubuh larva akan mempengaruhi enzim pencernaan dan penyerapan makanan (racun perut). Saponin juga dapat masuk melalui organ pernafasan sehingga menimbulkan rusaknya membran sel dan proses metabolisme terganggu Haditomo (2010). Alkaloid yang masuk ke tubuh larva dapat mendegradasi dinding sel dan merusak sel, serta menggangu sistem kerja syaraf larva nyamuk. Tanin meningktakan protein pada sistem pencernaan larva sehingga proses penyerapan protein dalam sistem pencernaan menjadi terganggu Hairani (2014).

Mortalitas pada larva uji selanjutnya digunakan untuk menghitung nilai Lethal Concentration ( $\left.\mathrm{LC}_{50}\right)$. Lethal Concentration $\left(\mathrm{LC}_{50}\right)$ adalah konsentrasi yang menyebabkan kematian 50\% larva uji. Dalam penelitian ini estimasi nilai $\mathrm{LC}_{50}$ dianalisis setelah pengamatan 96 jam. Estimasi nilai $\mathrm{LC}_{50}$ melalui uji analisis probit adalah pada konsentrasi ekstrak daun pisang sebesar 4638 ppm. Hasil tersebut lebih rendah dari konsentrasi uji yang digunakan yaitu 5000 ppm yang membunuh larva nyamuk sebanyak 58\% dari seluruh populasi sampel yang digunakan dalam penelitian. Sehingga dapat dikatan bahwa penelitian ini berhasil mematikan larva sebanyak 50\% dengan konsentrasi 5000 ppm.

Penelitian terdahulu dilakukan oleh Jamal et al. (2016) tentang efektifitas larvasida ekstrak kulit pisang raja (Musa paradisiaca var. Raja) terhadap larva Aedes sp. Instar III didapat hasil $\mathrm{LC}_{50}$ sebesar 0,516\% setara dengan $5160 \mathrm{ppm}$. Penelitian yang sama juga dilakukan oleh Komala et al. (2018) yaitu tentang ekstrak metanol bonggol pisang ambon (Musa acuminata L. Cv. Gros Michel) terhadap Aedes aegypti dan diperoleh hasil bahwa ekstrak bonggol pisang ambon efektif sebagai larvasida nyamuk $A$. aegypty dengan nilai $\operatorname{LC}_{50} 700,086 \mathrm{ppm}$. Sedangkan ada pula penelitian dari Rathy et al. (2015) bahwa gagang bunga pisang (Musa paradisiaca L.) memiliki kemampuan mortalitas $100 \%$ terhadap larva A.aegypti pada konsentrasi $0,5 \mathrm{mg} / \mathrm{ml}$ setara dengan $500 \mathrm{ppm}$ dalam waktu $24 \mathrm{jam}$. Sehingga dapat disimpulkan bahwa ekstrak daun pisang (Musa paradisiaca L.) pada konsentrasi 5000 ppm juga efektif sebagai larvasida walaupun tidak seefektif ekstrak bonggol pisang ambon dan gagang bunga pisang yang pada konsentrasi rendah sudah dapat mematikan larva nyamuk. Dikarenakan pada bonggol pisang dan gagang bunga pisang lebih banyak mengandung senyawa bio-aktif dari pada daun pisang.

Penelitian ini menggunakan larva Aedes aegypti instar III, karena larva nyamuk instar III sudah memiliki alat-alat tubuh yang lengkap terbentuk dan struktur dinding tubuhnya belum mengalami pengerasan sehingga sesuai untuk perlakuan, selain itu larva instar III merupakan sampel penelitian yang menjadi standar WHO WHO (2011).

Berdasarkan hasil uji Kruskall Wallis diperoleh hasil signifikasi 0,001 . Hasil tersebut $<0,05$ yang berarti Ha pada penelitian ini diterima dan Ho ditolak. Ho ditolak dikarenakan pada hasil penelitian dari setiap konsentrasi ekstrak daun pisang menyebabkan kematian terhadap larva nyamuk Aedes aegypti terdapat perbedaan yang nyata antara konsentrasi 1000 ppm hingga 5000 ppm. Berdasarkan hasil di atas maka ekstrak daun pisang memiliki pengaruh sebagai larvasida terhadap larva nyamuk Aedes aegypti.

Kemudian pada uji lanjutan yaitu uji Mann-Whitneydapat dilihat pada Tabel 3 dari hasil tersebut dapat dilihat dari semua kelompok uji cenderung signifikan dikarenakan nilainya $<0,05$ kecuali pada aquades terhadap konsentrasi 1000 ppm dengan 2000 ppm memiliki nilai hasil >0,05 yaitu 0,098 sehingga dikatakan konsentrasi 1000 ppm dengan 2000 ppm tidak memiliki perbedaan yang signifikan. Hasil tersebut juga dapat dilihat pada Tabel 1 rata-rata kematian pada konsentrasi 1000 ppm dan 2000 ppm tidak memiliki jarak yang jauh. Perbedaan yang signifikan didapat pada kontrol dan 1000 ppm dikarenakan menurut Amalia (2014) aquades tidak mengandung senyawa yang dapat membunuh larva sehingga tidak didapat kematian pada larva nyamuk. Sedangkan pada $1000 \mathrm{ppm}$ memiliki senyawa yang dapat membunuh larva tetapi kandungan senyawa tersebut kecil sehingga kurang efektif dalam membunuh larva. Kematian yang rendah dapat diakibatkan oleh bebrapa faktor diantaranya kadar konsentrasi ekstrak dan kondisi fisiologis larva Hairani (2014). Menurut Putri (2012) konsentrasi rendah memiliki kandungan senyawa yang sedikit sehingga menimbulkan kematian yang rendah terhadap larva. Semakin tinggi konsentrasi ekstrak maka semakin tinggi kematian yang ditimbulkan karena kandungan senyawa semakin tinggi. Data signifikakasi dikarenakan hasil pada tiap-tiap uji memiliki perbedaan kematian larva yang berbeda akibat konsentrasi senyawa yang terkandung pada masing-masing uji.

\section{KESIMPULAN}

Ekstrak daun pisang (Musa Paradisiaca L.) memiliki efek daya mortalitas terhadap larva nyamuk Aedes aegypti. Nilai LC50 ekstrak etanol daun pisang untuk larva Aedes aegypti sebesar 4638 ppm. Konsentrasi yang efektif untuk membunuh larva nyamuk Aedes aegypti yaitu 5000 ppm selama 96 jam.

\section{KONTRIBUSI PENULIS}

Penulis pertama berperan utama dalam pengumpulan data, sedangkan penulis kedua membantu dalam penyusunan artikel.

\section{PENDANAAN}

Penelitian ini menggunakan dana pribadi peneliti.

\section{UCAPAN TERIMA KASIH}

Penulis mengucapkan terima kasih kepada berbagai pihak yang telah membantu dalam penelitian ini. 


\section{REFERENSI}

Amalia, R. (2014). Daya bunuh air perasan daun mengkudu (Morinda citrifolia) terhadap kematian larva Aedes aegypti. Skripsi. Universitas Negeri Semarang. Semarang.

Asuquo, E. G., \& Udobi, C. E. (2016). Antibacterial and toxicity studies of the ethanol extract of Musa paradisiaca leaf. Cogent Biology, 2(1), 1-10. doi : 10.1080/23312025.2016.1219248

Deded, S., Anne, C., \& Cahyo, W. (2013). Ekstrak dan serbuk kayu jati sebagai larvasida Aedes aegypti. J. Ilmu Teknol. Kayu Tropis, 12(2), 101-107. Retrieved from https://docplayer.info/57694593-Ekstrak-dan-serbuk-kayujati-sebagai-larvasida-aedes-aegypti-larvicide-activity-of-teak-woodpowder-and-itsextract-to-dengue-fever-mosquito.html.

Haditomo, I. (2010). Efek larvasida ekstrak daun cengkeh (Syzygium aromaticum L.) terhadap Aedes aegypti. Skripsi. Universitas Sebelas Maret. Surakarta.

Hairani, S. (2014). Efektivitas ekstrak daun mundu (Garcinia dulcis) sebagai larvasida nyamuk Culex quinquefasciatus dan Aedes aegypti. Skripsi. Institut Pertanian Bogor. Bogor.

Jamal, N. A. S., Susilawaty, A., \& Azriful. (2016). Efektivitas larvasida ekstrak kulit pisang raja (Musa paradisiaca var.Raja) terhadap larva. Higiene, 2(2), 67-73. Retrieved from http://journal.uinalauddin.ac.id/index.php/higiene/article/view/1812

Kemenkes RI. (2016). Situasi DBD di Indonesia. Retrieved from https://www.kemkes.go.id/download.php?file=download/pusdatin/infodati n/infodatin\%20dbd\%202016.pdf

Komala, N. S., Budianto, H. B., \& Basuki, E. (2018). Studi Toksisitas: Ekstrakmetanol bonggol pisang ambon (Musa acuminata L. cv. Gros Michel) terhadap Aedes aegypti (Diptera: Culcidae). ASPIRATOR, 10(2), 93-102. $\quad$ Retrieved from https://ejournal2.litbang.kemkes.go.id/index.php/aspirator/article/view/217

Listyorini, I. P. (2012). Uji keamanan ekstrak kayu jati (Tectona Grandis L.F) sebagai bio-larvasida Aedes Aegypti terhadap mencit. Skripsi. Universitas Negeri Semarang. Semarang.

Nadila, I., Istiana., Wydiamala, E. (2017). Aktifitas larvasida ekstrak etanol daun binjai (Mangifera caesia) terhadap larva Aedes aegypti. Skripsi. Universitas Lambung Mangkurat. Banjarmasin.

Putri, B. Y. (2016). Uji aktivitas larvasida fraksi aktif daun bakau minyak (Rhizophora apiculata Blume) terhadap larva Nyamuk Aedes aegypti Linn. Skripsi. Universitas Sriwijaya Indralaya. Indralaya.

Raharjo, B. (2006). Uji kerentanan (Susceptibility Test) nyamuk Aedes aegypti (Linneaeus) dari Surabaya, Palembang dan beberapa wilayah di Bandung terhadap larvasida temephos (Abate $1 \mathrm{Sg}$ ). Retrieved from http:digilib.bi.itb.ac.id/go.php?id=jbptitbbi-gdl-s1-2006bayuraharj-1539

Rathy, M., Sajith, U., \& Cc Harilal. (2015). Plant diversity for mosquito control : A preliminary study. International Journal of Mosquito Research, 2(1), 29-33. Retrieved from http://www.dipterajournal.com/vol2issue1/21-6.1.html

Riyadi, Z., Julizar, J., \& Rahmatini, R. (2018). Uji efektivitas ekstrak etanol biji rambutan (Nephelium lappaceum L.) sebagai larvasida alami pada larva nyamuk Aedes aegypti. Jurnal Kesehatan Andalas, 7(2), 233-239. doi: 10.25077/jka.v7.i2.p233-239.2018

WHO. (2011). Comprehensive guidelines for prevention and control of dengue and dengue haemorrhagic fever. In WHO Regional Publication SEARO (Issue 1). doi: https://doi.org/10.1017/CBO9781107415324.004

Conflict of Interest Statement: The authors declare that the research was conducted in the absence of any commercial or financial relationships that could be construed as a potential conflict of interest.

Copyright (C) 2021 Karima and Ardiansyah. This is an open-access article distributed under the terms of the Creative Commons Attribution License (CC $\mathrm{BY})$. The use, dis- tribution or reproduction in other forums is permitted, provided the original author(s) and the copyright owner(s) are credited and that the original publication in this jour- nal is cited, in accordance with accepted academic practice. No use, distribution or reproduction is permitted which does not comply with these terms. 